\title{
Representation And Leadership Roles: Women Officials In Local Unions
}

Carrie G. Donald, (E-mail: cgdona01@louisville.edu), University of Louisville Rebecca C. Tribbey, University of Louisville

\begin{abstract}
In recent years, observers of the American labor movement have suggested that labor is undergoing a process of "feminization." Although women are increasingly present in national and international labor organizations, unions do not generally collect data on women in local union leadership. By studying union women at the local rather than the national level, however, the focus is on the level that most directly affects women's lives. In order to gain current information on the experiences of women in local unions today and their prospects for leadership, the Labor-Management Center of the University of Louisville conducted a survey of local union officials throughout Kentucky and neighboring states.
\end{abstract}

\section{INTRODUCTION}

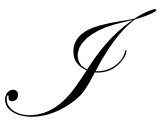

$\mathrm{n}$ recent years, observers of the American labor movement have suggested that labor is undergoing a process of "feminization." (1) This is due to the increasing numbers of women entering areas of the workplace that are historically male-oriented, and the increasing tendency of these women to join labor unions. In fact, women have now shown themselves more receptive to unionization of their workplaces than men. ${ }^{(2)}$ By 1997, women constituted 39 percent of all union members in the U.S. ${ }^{(3)}$ Although this percentage is still below their total workforce participation, women are joining unions at higher rates than men. Such an important change in union membership should impact the composition of union leadership. But has this shift in union trends indeed manifested itself in labor unions? Even in unions where women constitute the majority or a substantial number of the members, women are not proportionally represented in the leadership ranks. Often they are severely underrepresented. As women become new union members, have they, or long-term union women, experienced any corresponding strides forward in union participation and leadership?

Although women are increasingly present in national and international labor organizations, unions do not generally collect data on women in local union leadership. By studying union women at the local rather than the national level, however, the focus is on the level that most directly affects women's lives. In order to gain current information on the experiences of women in local unions today and their prospects for leadership, the LaborManagement Center of the University of Louisville conducted a survey of local union officials throughout Kentucky and neighboring states. Analysis of survey data has enabled a description of the general characteristics of women in local union leadership, and evaluates the atmospheres in which they rise to positions of authority. Assessment of female respondents in relation to their comparison group, men of similar standing in their unions, at the same level of union organization, has enabled conclusions to be drawn conclusions regarding whether women rise to leadership positions with similar union seniority, comparable experience, equal chances of election, and similar personal characteristics as men. This research has identified barriers that women face in attaining leadership positions in local unions. Although the environments of women's workplaces and unions will vary widely, there are suggested general guidelines that women and unions may follow in order to increase female participation in union leadership. 


\section{UNION WOMEN}

Until recently, labor unions were the preserve of white, blue-collar male workers. In the past few decades, however, unions faced a changing economic structure that precipitated the decline of unionized industries, such as heavy manufacturing. As the dominance of manufacturing gave way to the rise of the service sector, the makeup of unions themselves inevitably changed. Areas of steady union growth have occurred in industries composed of large numbers of women and minority workers, many of whom are considered "service" workers. ${ }^{(4)}$ An area of significant union growth is the public sector, which employs large numbers of women and minorities. Men still constitute the majority of union members; 15.2 percent of male workers are unionized, while only 11.5 percent of female workers are unionized. ${ }^{(3)}$ However, after many decades during which women were considered difficult to organize, women workers are now more likely to vote for a union than men, and their overall share of union membership is growing. ${ }^{(5)}$ In 1977, 28 percent of union members were female. By 1985, that percentage had risen to 34 percent, ${ }^{(6)}$ and by 1997, was up to 39 percent. ${ }^{(7)}$ The greatest proportion of women unionists is found in the public sector, though other industries with large numbers of women workers, such as health care, are also organizing many new female members. (6) Unions such as the Teamsters, American Federation of State, County and Municipal Employees (AFSCME), United Food and Commercial Workers (UFCW), and Service Employees International Union (SEIU) also have a substantial number of female members. ${ }^{(6)}$ Of important note are the teacher organizations, the National Education Association (NEA) and the American Federation of Teachers (AFT), to whom large numbers of female teachers belong. Teacher organizations originally acted as professional associations, until falling real incomes and other pressures compelled them to turn to collective bargaining. ${ }^{(6)}$ More recently, other professional groups to whom many female workers belong, especially within the health care field, have organized in an attempt to protect wages and maintain quality.

Women who join unions see a direct benefit in their paychecks. Union women earn 40 percent more than comparable non-union women, though union men still earn more. ${ }^{(7)}$ In addition to lower pay, union women confront obstacles specific to their gender. Male and female workers share similar concerns such as wages, working conditions, equal treatment, job security, and respect from employers, but women's concerns regarding gender discrimination, harassment, child care, maternity leave, flexible scheduling, and equal pay are usually greater ${ }^{(6)(5)}$ Women are also confronted with the reality that better-paying jobs and advancement opportunities are given to men more often than to women. $^{(5)}$ Many unionized industries are still male-dominated, and women within them face many barriers, such as difficulty in finding jobs, poor job assignments, stereotyping, sexual harassment, isolation, competitiveness, lack of respect, judgments made based on their appearance, and special, undue attention focused on what they do. ${ }^{(8)}$ Some women find that discrimination is subtle, though present. Most employers and unions are now aware of antidiscrimination laws. Blatant discrimination is not as common as it used to be, though for women in male-dominated workplaces, it is often an everyday reality. ${ }^{(8)(9)}$ Employers in unionized industries, though, sometimes do not have much experience working with female employees, and are wary of their abilities. Union women face the doubts of their male supervisors and coworkers who believe that women cannot handle challenging physical work. ${ }^{(8)}$

Union officials, whose ranks are overwhelming male, often do not give these issues the time and attention many women feel they deserve. Although many union women would like to raise awareness regarding their concerns, women often find it difficult to become active union participants. The most oft-cited obstacle is that of time constraints. Women, who still shoulder most of the burdens of housework and childcare, find it difficult to fit union activities, such as meetings, volunteer work, organizing, and union administration into their schedules. ${ }^{(10)}$ Meeting times may not be convenient, or women may not be able to arrange for child care during those times. ${ }^{(6)}$ When women's work and family responsibilities preclude involvement in union affairs, women find limited opportunities to join the ranks of union leadership.

\section{UNION WOMEN AS LEADERS}

Although women are a growing segment of the labor movement, few union leaders at the national level are women. National female leaders are likely to belong to unions dominated by women, such as the flight attendants union. ${ }^{(6)}$ Female leadership has been boosted by the current president of the AFL-CIO, John Sweeney, who has added 
more women to the AFL-CIO's executive council, and has emphasized the organization of non-union women. He has also established a Working Women's Department, in recognition of the importance of union women to the continued viability of the union movement. ${ }^{(11)}$ However, the new female presence on the national stage does not necessarily translate to female leadership at the local level. Most regional and national leaders arise from the local level, and therefore union women will first need to secure local positions to gain the experience necessary for higher office.

However, women experience certain gender-specific barriers, and therefore often have difficulty in attaining union office. Women who do hold official positions are generally less powerful than male union leaders. Those who are elected often occupy the position of secretary, a traditional role for women. ${ }^{(12)}$ Helen Elkiss argues that union women face a "glass ceiling" similar to that faced by women in the business world. ${ }^{(13)}$ Barriers exist at both local and higher levels. Women are especially underrepresented in top union leadership, particularly in positions like president. Union women are more likely to hold appointive rather than more powerful elective offices, and are not often placed in influential positions such as on the bargaining committee. ${ }^{(12)}$ Women often serve as stewards, and while such a position offers valuable experience, a steward is less powerful than other officials. ${ }^{(13)}$

The fact that women are not fully represented among union leadership is well documented. The question arises: does it matter? Although we do not want to overstate the differences between male and female leadership, past research has tended to support the idea that female leadership emphasizes cooperation and de-emphasizes hierarchy. ${ }^{(14)}$ In addition, unions are representative vehicles that are intended to accurately represent the interests of their memberships. In union cultures built around male solidarity and male organizational style, it is crucial that women break into the ranks of leadership. However, labor unions present particular challenges for the women who aspire to leadership. Election is especially difficult for women in male-dominated unions, where even simple acceptance is not easily won. It is believed that female union leaders are customarily required to commit a greater amount of hard work and personal sacrifice than men in order to reach union office. Previous studies have found that women perform more family tasks than men do. Because of these responsibilities, women tend to join union leadership at an older age than men do, after their children are grown. ${ }^{(13)}$ In fact, some studies have found that female union leaders are often single or divorced, and childless, and presumably have fewer family responsibilities. On the job and within the union, some union women face discrimination and harassment, and partly as a result, feel low self-confidence in their leadership abilities. They may also have less confidence due to the fact that they receive less union training than their male counterparts do. ${ }^{(13)}$

\section{THE SURVEY PROJECT}

In order to obtain data regarding male and female union leaders, and to identify barriers and opportunities for union women, the Labor-Management Center, with financial assistance from an internal university grant, conducted a survey of union officials throughout Kentucky. In June 2000, surveys were mailed to officials identified by two lists: local union officials as listed in the 2000 Directory of Labor Organizations from the Kentucky Labor Cabinet, and local teacher presidents as listed by the Kentucky Education Association website. According to the Directory of Labor Organizations, there are 700 local labor unions in Kentucky, and about 200 female officials. In addition, the Kentucky Education Association has 190 local labor organizations.

Prior to mass distribution of the surveys, a selected focus group of male and female union leaders reviewed the surveys, and necessary revisions were made to the instruments to clarify and expand questions. Surveys were then mailed to all local union presidents and other union officials with available addresses. The total number mailed was 865. Surveys were distributed across a wide spectrum of industries. A follow-up postcard encouraging recipients to complete the survey was mailed, and then a second mailing of surveys was sent to officials who still had not responded.

The three general areas of survey questioning of male and female union officials were: 1) personal and occupational information about each official; 2) descriptive data on the respondent's union and its membership; and 3) the perspectives of male and female officials on women in unions and women officials. (Appendix) In order to 
examine any correlation between gender and experience, this last section of the survey posed attitudinal questions, including the chance for respondents to write open-ended responses.

\section{SURVEY RESULTS}

\section{Respondent Characteristics}

Out of 865 individuals on the mailing list, 185 union officials responded. Excluding the 57 surveys returned to us as undeliverable, received a response rate of 22.9 percent was received. One-hundred seventeen respondents were male; 67 were female. In percentage terms, 63 percent of respondents were male, 36 percent female. The gender of one respondent was unknown, due to no answer for that question. Most respondents were Caucasian; nine were African American, one was Asian American, one was Native American, and two others reported being Native American/Caucasian. Most respondents held the position of local union president. Other positions held included: vice president, secretary-treasurer, recording secretary, financial secretary, business representative/agent/manager, steward, district president, and executive board member. A majority of these officials held their positions as unpaid, part-time positions. 43.2 percent were paid, though those not working full-time for the union generally received only nominal monetary rewards for their efforts. Only 18.3 percent performed their duties as a full-time job. Of those responding to a question about their term of office, 46 respondents reported a one-year term, 41 reported a two-year term, 72 reported a three-year term, six held a four-year term, one was serving an eight-year term, and five held their position indefinitely. In their work lives, only 13 respondents, excluding those who worked for the union full-time, reported holding supervisory positions. These included four teachers, one principal, an administrator, a letter carrier, yardmaster, mechanic, mold assembler, security officer, steelworker, and a government worker.

Personal and family characteristics of male and female respondents contradicted past research, in some respects. Some studies have shown that union women with young children do not try to achieve a leadership position because their time and energy is spent on raising their children. ${ }^{(13)}$ However, in this survey, neither men nor women with young children take on union duties in large numbers. There was no significant difference in the number of children that male and female respondents reported as having (an average of 2.1 for men, and 1.8 for women), nor was there much difference in the ages of the children (an average of 22.4 for men, and 24.1 for women). Although it was expected that more women than men would wait until their children were grown before assuming union responsibilities, both men and women respondents seemed to be at a similar stage in their lives. This is also suggested by the fact that there was no significant difference in the ages of the male and female respondents, 49.3 being the average age for males and 50.0 the average age for females. The survey findings did support previous studies with respect to marital status. A cross-tab analysis revealed that women respondents were more likely to be single than male respondents. 82.1 percent of men responding were married, while only 68.2 percent of women responding were married.

There was also a significant difference, shown by cross-tab, in educational level between men and women, the latter of whom were more likely to have achieved a higher educational level. This is probably due to the large number of female teachers, many of whom had completed postgraduate work, who responded to the survey. The results were in line with previous research, which indicates that union women are likelier to have a college degree than union men. ${ }^{(4)}$

\section{Union Characteristics}

Members of the Kentucky Education Association (KEA) provided the greatest response to the survey. Fiftysix teachers responded, though many of them stated that they considered themselves members of a professional organization, not "union" members. This is due to the fact that Kentucky public school teachers do not have collective bargaining rights, and cannot strike. The next largest response from one union or industry came from postal workers, of whom twelve American Postal Workers Union (APWU) members, fifteen National Association of Letter Carriers (NALC) members, and three members of the National Rural Letter Carriers (NRLC) completed surveys. Thirteen members of railroad unions, eight members of Paper Allied-Industrial, Chemical and Energy Workers (PACE), nine 
members of the Communications Workers of America (CWA), and seven members of the United Steelworkers Association (USWA) responded. The survey received six replies from the United Auto Workers (UAW), six from the United Food and Commercial Workers (UFCW), and four from the International Brotherhood of Electrical Workers (IBEW). Three replies each were received from the International Association of Firefighters (IAFF), International Association of Machinists and Aerospace Workers (IAMAW), Service Employees International Union (SEIU), United Mine Workers of America (UMWA), and the Union of Needletrades, Industrial and Textile Employees (UNITE). One or two surveys each were received from: American Federation of State, County and Municipal Employees (AFSMCE); International Union of Electronic, Electrical, Salaried, Machine and Furniture Workers (IUE); American Nurses Association (ANA); American Federation of Government Employees (AFGE); Amalgamated Transit Union (ATU); Graphic Communications International Union (GCIU); Security, Police, Fire Professionals of America; Bricklayers; Teamsters; Iron Workers; Tobacco Workers; Laborers; Painters; Plumbers and Pipefitters; Roofers; Operating Engineers; Carpenters; Hotel and Restaurant Employees; Theatrical Stage Employees; Louisville Musicians Local; American Federation of Teachers. Besides the KEA, female respondents belonged to: APWU, NALC, NRLC, CWA, UAW, UFCW, USWA, IAMAW, SEIU, AFSCME, ANA, UNITE, IUE, and Louisville Musicians Local. In all, a wide variety of individuals, unions, and industries are represented in the survey results.

A variety of unions are also represented with regards to size. The smallest reported local unions were made up of one active member (three locals of NALC); the largest union had a membership of 19,500 (UFCW). However, it is important to note that membership sizes may not be comparable. Although survey questions specifically referred to local union characteristics, some respondents also held positions at the district level, and may have provided data for the district rather than the local. Unions varied considerably in the number of female members. Ten respondents, mostly belonging to railroad workers unions, reported having no female members. Locals with no women among its ranks were affiliated with: United Transportation Union, Transportation Communications Union, the Locomotive Engineers, Maintenance of Way Employees, one local of the IAFF, and a NALC local in which only one postal worker was employed. Not surprisingly, teacher locals had the largest proportions of female members, though unions within such industries as health care, sewing, and the public sector also reported significant numbers of female members. Again, not surprisingly, many of these industries involve traditional female occupations such as education and nursing. Several other respondents reported high proportions of women members working in industries such as communications and packaging and warehousing. Unions to which many women belong were reported as having higher numbers of female officials; the higher the percentage of women members, the higher the number of female officers served the union. Respondents reported that women most frequently held the position of steward. Women were least likely to hold the post of business agent.

Female respondents were more likely than male respondents to belong to unions that averaged lower pay for their members. This may be due to the fact that there are few women in the skilled trades and construction, occupations which average higher pay than other union jobs. ${ }^{(6)}$ By cross-tab, it was found that members of male respondents' unions earned more than members of females' unions. A t-test showed that, on average, the male respondents also personally earned more money than the female respondents. Thirty-seven, or 31.6 percent of, men reported annual earnings of $\$ 50,000$ or over, but only nine, or 13.4 percent of, women earned this much.

Overall, the unions were not very likely to have established women's committees, and were even less likely to provide child care for union meetings. Thirty respondents, or 16.7 percent, said that their unions had women's committees. Among the thirty, four were teachers, three each belonged to IAMAW, USWA, UAW, and two each belonged to PACE, IBEW, and CWA. Only three respondents belong to unions that provide some form of child care during union meetings. Two of these respondents were teachers, and one was a rural letter carrier. The teachers said that members could bring their children to the meetings, or that older students were available to entertain younger children. The letter carrier reported that her local union had an auxiliary program for spouses and children who have their own meeting. 


\section{Union Experience And Gender}

Women leaders are often held to a higher standard than male leaders, and it can take them longer to achieve a leadership position. We hypothesized that the female officials in the survey would have had to gain considerably more experience with union affairs than comparable male officials before they were able to attain their current position. However, the survey results indicated, through cross-tab analysis, no statistically significant difference between men and women as to whether they held previous official positions with the union. The male and female respondents had substantial experience with union affairs; 66.3 percent of all respondents had held previous union positions. Men and women were also evenly matched with respect to other offices or positions currently held within the union, such as committee chair. 45.1 percent of total respondents held another union position in addition to their primary one. It was posited that more male respondents would hold positions with a union-affiliated organization such as a central labor council or state AFL-CIO. But again, there was no significant difference between men and women in this regard. Most respondents did not hold any position with a union-affiliated organization; only 18.1 percent did so.

As to the theory that women reach union office at an older age than men, the survey results bore this out. ${ }^{(13)}$ Although the average age of the male and female respondents was quite similar, 49.3 for males and 50.0 for females, a $\mathrm{t}$-test showed a significant difference in the ages at which men and women first take office. Male respondents reported attaining elective office at a younger age, an average of 34.9, than female respondents, whose average age at first election was 38.3. On the other hand, there was no statistically significant male/female difference in the length of union membership. Male respondents had been union members for an average of 22.2 years, while female respondents had been members for an average of 20.7 years. Nor was there any statistically significant difference in the length of time men and women were union members before first being elected to office. Once reaching office, men do seem to hold their positions longer; there was a significant difference in the length of time male and female officials had held their current position. On average, men have served in their official position for 7.5 years, while women have occupied their position for an average of 4.8 years.

In addition, union officials were asked what kinds of union activities they were involved in before they achieved elective office. In particular, respondents were asked to check any or all of the following activities in which they had participated: being appointed to a union position; volunteering for the union; serving on a union committee; initiating grievance(s); attending training program(s) for union members, or training programs for management and leadership skills, etc.; and running for election to a union position, but not winning. The most common activities of male teachers, in order of frequency, were volunteering, serving on committee, attending training, and being appointed to a position. These same activities, in the exact same order, were also the most common activities that female teachers reported undertaking before attaining their own elective offices. Among non-teachers, responses were not as parallel. The most common activity for non-teacher men was volunteering for the union. The second most common experience was being appointed to a union position. Tied for third were serving on a union committee and attending training. Like the male respondents, women reported that their most common activity prior to election was volunteering. However, second in frequency was attending training. Tied for third were being appointed to a position and initiating a grievance.

There was no perceptible discouragement for union women who seek higher office. No statistically significant difference was found between men and women in a cross-tab analysis as to whether they planned to run for an office higher than their current level. Sixty-five percent of all respondents said they did not plan to run for a higher position; 9 percent said they did plan to run; and 26 percent said they were not sure. The male and female respondents who chose not to run for higher office cited similar factors, such as the hassle of politics, too many home responsibilities, not enough time, stress and fatigue, a feeling that it was "time for new ideas and new people," retirement, or that they would have to move away to assume a higher union office. Many respondents were satisfied with their current status. 


\section{Perceptions Of Female Union Leaders}

Survey recipients were queried about the likelihood of being elected to office for men and for women. Officials were asked whether it was: much easier for men than women to be elected to office in their unions; a little easier for men than women to be elected; same likelihood for men and women of being elected; a little easier for women than men to be elected; or much easier for women than men to be elected. By large, most teachers, both male and female, felt that men and women had the same likelihood of being elected to union office. Half of the twelve male teachers responding and 60.5 percent of the 43 women teachers responding believed that men and women were equal in this respect. A sizable proportion of female teachers, 34.9 percent, said that it was much easier for women to be elected in their teacher unions.

Table I: Likelihood Of Election For Men And Women: Teacher Responses

\begin{tabular}{lllll}
\hline & \multicolumn{2}{c}{$\begin{array}{c}\text { Male Responses } \\
\text { Percent }\end{array}$} & Count & Female Responses \\
Percent & Count \\
Much easier for men & $16.7 \%$ & 2 & $2.3 \%$ & 1 \\
Little easier for men & $8.3 \%$ & 1 & $2.3 \%$ & 1 \\
Same likelihood & $50.0 \%$ & 6 & $60.5 \%$ & 26 \\
Little easier for women & $16.7 \%$ & 2 & $0.0 \%$ & 0 \\
Much easier for women & $8.3 \%$ & 1 & $34.9 \%$ & 15 \\
Totals & $100 \%$ & 12 & $100 \%$ & 43 \\
\hline
\end{tabular}

Among non-teachers, 60.6 percent of male respondents believed that men and women had the same likelihood of being elected, but female respondents were not so confident; only 45 percent of women responded similarly. However, considerable proportions of both male and female respondents said that men were a little likelier to be elected, or that men were much likelier to be elected.

Table II: Likelihood Of Election For Men And Women: Non-Teacher Responses

\begin{tabular}{|c|c|c|c|c|}
\hline & \multicolumn{2}{|c|}{ Male Responses } & \multicolumn{2}{|c|}{ Female Responses } \\
\hline & Percent & Count & Percent & Count \\
\hline Much easier for men & $21.2 \%$ & 21 & $15.0 \%$ & 3 \\
\hline Little easier for men & $17.2 \%$ & 17 & $20.0 \%$ & 4 \\
\hline Same likelihood & $60.6 \%$ & 60 & $45.0 \%$ & 9 \\
\hline Little easier for women & $0.0 \%$ & 0 & $10.0 \%$ & 2 \\
\hline Much easier for women & $1.0 \%$ & 1 & $10.0 \%$ & 2 \\
\hline Totals & $100 \%$ & 99 & $100 \%$ & 20 \\
\hline
\end{tabular}

The greatest difference between teachers and non-teachers occurred on the question of whether their unions had the right number of male and female officials. Results likely reflect the composition of the unions themselves, with teacher unions being predominantly female. Survey recipients were asked whether their local union: needs many more female officials; needs a few more female officials; has about the right number of male and female officials; needs a few more male officials; or needs many more male officials. Male teachers were split on this issue, with the largest proportion, 41.7 percent, replying that the union had the right number. Over 63 percent of female teachers, though, said their unions needed a few more male officials. 
Table III: Need For More Male Or Female Officials: Teacher Responses

\begin{tabular}{lccccc}
\hline & \multicolumn{2}{c}{ Male Responses } & \multicolumn{2}{c}{ Female Responses } \\
& Percent & Count & Percent & Count \\
Need many more females & $16.7 \%$ & 2 & $2.4 \%$ & 1 & 1 \\
Need a few more females & $8.3 \%$ & 1 & $2.4 \%$ & 8 & 26 \\
Already have right number & $41.7 \%$ & 5 & $19.5 \%$ & $63.4 \%$ & 5 \\
Need a few more males & $25.0 \%$ & 3 & $12.2 \%$ & 41 \\
Need many more males & $8.3 \%$ & 1 & $100 \%$ & 41 \\
Totals & $100 \%$ & 12 & & \\
\hline
\end{tabular}

Among non-teachers, there was no strong feeling on the part of female respondents that women were underrepresented in their local unions. Only one woman said that many more female officials were needed, in contrast to the 17 men who felt this way. It must be kept in mind, however, that female respondents belonged to unions with larger numbers of female members and officers. Most men and women respondents believed that their unions had the right number of male and female officials, or needed a few more female officials.

Table IV: Need For More Male Or Female Officials: Non-Teacher Responses

\begin{tabular}{lccccc}
\hline & \multicolumn{2}{c}{ Male Responses } & \multicolumn{2}{c}{ Female Responses } \\
& Percent & Count & Percent & Count \\
Need many more females & $18.9 \%$ & 17 & $5.3 \%$ & 1 & 7 \\
Need a few more females & $42.2 \%$ & 38 & $36.8 \%$ & 6 & 4 \\
Already have right number & $37.8 \%$ & 34 & $31.6 \%$ & $21.0 \%$ & 4 \\
Need a few more males & $1.1 \%$ & 1 & $5.3 \%$ & 1 \\
Need many more males & $0.0 \%$ & 0 & $100 \%$ & 19 \\
Totals & $100 \%$ & 90 & & \\
\hline
\end{tabular}

Although the majority of women responding said that they had not been the target of sexual harassment in the unionized workplace, a greater percentage of women, 23.1 percent, than men, 5.2 percent, said they had indeed experienced sexual harassment. However, when questioned as to whether they had personally witnessed sexual harassment of others in the unionized workplace, men and women gave similar responses. 22.6 percent of men and 28.8 percent of women answered that they had witnessed sexual harassment of women. 15.8 percent of men and 13.6 percent of women reported witnessing sexual harassment of male coworkers. Both male and female respondents clearly perceived that women were more often victims of sexual harassment, and men and women were in agreement regarding the extent of sexual harassment in their workplaces.

The response to the question of whether each official had to make personal sacrifices to carry out union duties surprised us, because it ran contrary to what past research let us to expect. Although the majority of both men and women reported making personal sacrifices for the union, a larger percentage of men, 76.7 percent, than women, 60.0 percent, said they had made sacrifices. Because women generally shoulder more family responsibilities, it might be expected that women had to cut back on family duties and activities more than men. However, the men responding to the survey told us that they had had to miss many family activities due to their union service. They cited time away from their spouses and children, and missing ballgames, family outings, and vacations. They also sacrificed overtime, other income, sleep, personal time, and lost holidays. In response to the question about what sacrifices had been made, one male respondent answered, "My family for 26 years." A few women, though, confirmed the belief that women in particular are restricted by family duties. One woman said, "Women have responsibilities to their children and their home life that do not seem to hinder men. As a result, women find it difficult to completely fulfill a commitment to 
elected office." Another commented, "There are very few women in leadership positions within the union due to the sacrifice it requires of your spouse. Men are not as appreciative of the time spent on union duties by their wife, as women are of husbands in the same role. Women are constantly forced to choose." Other women told us that their union duties had taken a toll on their families. One female official said she often arrived home "late after working hours tired and grumpy from being overworked." Hopefully, the survey is indicating that change is afoot, and that men are becoming equal partners with their wives with respect to family and household responsibilities. It is clear that both the male and female respondents felt they lost a great deal of family time due to union obligations.

Previous studies have found that women and men have different views regarding the barriers to female leadership. ${ }^{(13)}$ When asked to identify such barriers, men generally believe that marriage and family duties prevent women from participating in union leadership. Women are more inclined to report that they are held back from leadership by a lack of respect and seriousness shown towards them by union men. ${ }^{(13)}$ In the study, an overwhelming majority of both male and female officials told us that they did not believe women faced gender-based barriers to elective or appointive office in their unions at all. 88.4 percent of men and 85.7 percent of women did not perceive any barriers for women in their own local unions. A slightly smaller percentage, 84.5 percent of men and 82.8 percent of women, said that they personally had not faced any barriers to office. Women respondents who reported barriers said that men did not listen to women, and that union members had a perception of men as the natural leaders. One female distillery worker said she was "viewed as being arrogant when a man would have been viewed as authoritative or assertive." She overcame this barrier by "hard work, working twice as hard to prove [she was] capable." Another woman said that other union members did not take her seriously. To deal with this, she said, "I speak when I know the facts and have learned to ignore the gripers." Some union men also reported that their female counterparts run into barriers. They said that many union men would rather deal with male officers, that the "good ol' boy" network served to exclude women from leadership, and that women had to work harder to prove their worth. One respondent said, "The men think a man would have an edge dealing with other males."

In reporting barriers personally faced, many respondents recounted hurdles that they did not perceive as gender-based. Union officials have confronted hostility and intimidation from management, racial discrimination, lack of trust from union members, and cliques and jealousies among union members. Some respondents said they had to deal with the perception by management that they were troublemakers, all the while trying to meet the high expectations of the workers they represented. Of the females reporting gender-based obstacles, they said they had faced discriminatory treatment, and had been the recipients of derogatory remarks and a lack of respect. However, a great majority of both women and men said they had not personally experienced any impediments to union office, or that the impediments were faced by men and women alike.

Perhaps because so many officials do not perceive any particular barriers for women, some unions do not make an effort to recruit women for leadership positions. However, the majority of unions do recruit female leaders; 60.7 percent of male officials and 58.6 percent of female officials said that their unions had made such recruiting efforts. Many teachers emphasized that there was no need for special recruitment for women within their field. Other union officials described their recruiting efforts, which included: personal contact and encouragement for women, nomination to offices, appointments to committees, formation of women's committees, training classes, asking women to attend union meetings and to volunteer, announcements through union newsletters, sending female members to conferences, and "talking to some of the female apprentices about the importance of their continued duties in the union." Many respondents said they had made personal, informal attempts to recruit women for leadership positions. One male official described a directed recruitment effort: "We were in need of a financial secretary, and knew one woman who had some prior experience in that area. The executive board then made an effort to recruit her. We were successful." Some officials said that they made recruitment efforts, but were unsuccessful, because the women they approached did not want to take on such a commitment. About half of responding officials, 58.0 percent of men and 49.1 percent of women, believed that union leadership should take more action to encourage greater female participation and leadership in unions. Some teachers said that male teachers, rather than female teachers, needed encouragement to participate in the union. The respondents gave many suggestions to persuade and support women toward leadership roles. They said unions should encourage women to: take leadership classes, attend union meetings, run for positions such as steward, attend seminars, and volunteer for committees. The respondents also 
suggested that unions should: recruit women to join the union, try to organize non-union female workers, make females feel more comfortable in the union, keep women informed about union affairs, be more sensitive to women's issues, give women decision-making roles, and educate women on how to run campaigns and be effective leaders. Still, a sizable portion of respondents felt that their unions were currently doing enough to promote female participation, and some were resistant to the idea that recruitment efforts should be targeted to one gender. "I believe male or female union members should have the same desire to step forward, and gender should not create a 'recruitment," said one male official. Another union man agreed, "Instead of trying to get women in leadership roles, we should work to seek the best people possible to further unionism."

There was a significant difference between men and women on the question of whether women officials are different from male officials in leadership style or activities. More female officials, 66.7 percent, than male officials, 38.4 percent, said that women are different kinds of leaders than men. Union women were more likely to report the beneficial aspects of female leadership. The respondents' descriptions of female leaders were almost entirely positive, though consisted mostly of traits ordinarily considered "feminine." Women leaders were described by both men and women as calm, nurturing, caring, compassionate, patient, easygoing, organized, goal-oriented, thorough, inclusive, consensus-building, sensitive to personal and family issues, and passionate about causes. One woman said that women "remember to do the touchy, feely kind of things males may overlook." However, a few respondents pointed out that some of these traits are viewed as weaknesses by fellow union members, who may prefer strong and aggressive leaders, rather than leaders who are viewed as "soft" or emotional. One male respondent said, "Women seem reluctant to voice their opinions when they know a lot about a subject," and a female respondent commented that women are afraid to stand up to the men. Another female respondent acknowledged the perception that men have a "...stronger leadership style. However, females who have been elected to union positions have demonstrated some of this same strength." Male leaders were described as: dominating, aggressive, reactionary, and "hard nosed." On the other hand, many respondents voiced opinions similar to the male respondents who said, "Good leadership has nothing to do with your gender," and "The requirements of leadership are the same for men or women. Style and activities are governed by personality, education, and experience...."

\section{CONCLUSIONS}

By focusing on women at the local level, this research has provided some of the answers to questions concerning the views of local union officials regarding female leadership, and the experiences of men and women who have made successful journeys to union leadership. The characteristics of success for these men and women may provide insight and direction for other union members, particularly women who have had difficulty breaking into union leadership or who do not believe they could fulfill a leadership role. Success often requires considerable planning, training, and networking. Union women often lack the contacts with fellow union members that are needed to secure support for a run for office. Many of the respondents, both male and female, mentioned the "good ol' boy" mentality still widespread among unionized workplaces. Women therefore need to network with each other and with sympathetic male union members. It is important to note that the individuals surveyed were those who were successful in attaining union office. To get a complete picture of the obstacles to office, a future study would need to incorporate the input of those who tried for a leadership position, but failed. However, it could be difficult to identify and locate these individuals.

Although women's families can take a part in easing time constraints, there are other areas in which unions could take responsibility. Union officials can implement initiatives to boost female participation and leadership.

Unions at the national and local level can create leadership training programs aimed at women. ${ }^{(1)}$ Training workshops instruct women in the basic skills of union leadership, including collective bargaining and arbitration. Workshops also provide female solidarity and the opportunity for women to learn from one another. ${ }^{(13)}$ The pool of union women from which leaders are selected can grow with a concerted effort to organize non-union women. Many more female organizers are needed to encourage these women to consider organizing their workplaces and running for leadership positions. ${ }^{(11)}$ Women's committees within local unions can serve a vital support function for union women, and as a tool to communicate women's concerns to union officials and the rank-and-file. Other possible solutions for a 
lack of female participation include union affirmative action plans, a mentoring program, and family-friendly meeting times. ${ }^{(13)}$

Most of the survey respondents do not support the assumption that women are not adequately represented in union leadership. From the survey results, it was determined that a sizable proportion of union officials are indeed trying to include women, though many believe that their unions must go farther still in bringing women into union activities and leadership. It is positive and encouraging that both men and women report looking beyond gender in assessing leadership potential of fellow union members. A large number of comments were made supporting the notion that union members should be judged according to their skills and abilities, not according to their gender. This survey instrument, however, does not measure how often this stated belief is put into action, or whether rank-and-file members believe and act the same as their officers.

The barrier faced by most respondents, both male and female, was not based on gender. These officials stated that participation in general is hard to come by, and that they would welcome the involvement and assistance of any union members, male or female. One teacher said, "It is hard to get new teachers to join, and member teachers to be active. They are willing to come and complain but can't get them involved even to work on salaries." Some female teachers were concerned that male teachers in their schools rarely involved themselves in union affairs, especially at the elementary level. One male steelworker commented that, "Just a small number in our local seek office. Most want someone else to do everything - and then complain if it doesn't suit them." Another male respondent told us, "Nobody wanted to be union steward. [The] offer was available to men and women alike. Finally I was nominated and elected." Because union duties often involve a great deal of time and personal sacrifices for small (if any) pay, there is little incentive for union members of either sex to seek office. One respondent described his union service as "Excessive hours of work in a high stress environment." Many union officials also pay their own expenses for union work, including communication and travel costs. Some officials do not accept the small pay or reimbursement when it is offered, out of a sense of service to their fellow union members. A few of the respondents are serving their unions past the end of their terms, because no one else is willing to take over. One respondent described his term of office as "one year to life." Many officials said they welcomed participation by anyone, and expressed the sentiment that "Those who want to make a difference will regardless of sex, race, or religion."

Many respondents described other barriers that pertained to men and women alike. Teachers cited their need for stronger unions, and their support for collective bargaining rights for public employees in the state of Kentucky. Due to their lack of power, teachers complained that administrators and school boards did not respect their unions or take their concerns into account. A female teacher commented, "Most local education associations do not assert themselves because the bulk of active members come from female, elementary teachers." One teacher told us, "The local I serve is not a strong union... Some surrounding districts do negotiate with their teachers for salary, benefits, etc., but my district is not one of these. In the districts where school boards do voluntarily negotiate with teachers, employees (both teachers and support staff) have higher pay, better benefits, and increased moral [sic]."

Other barriers cited by the respondents included: lack of racial diversity, racial discrimination, and a lack of support for, or understanding of, unions from members of the community. Several respondents commented that the general public needs to be educated about the benefits that unions provide for both men and women. They also felt that barriers to leadership should be eliminated for all union members. "We must all work to insure that all members, regardless of gender, race, or ethnic background have a full opportunity to participate at all levels, to the full extent of abilities, in our respective unions" (emphasis in original). Generally, the respondents take pride in the services they provide for fellow union members. Many union officials find their work rewarding and valuable, though very tiring and often stressful.

The goal has been to improve the current understanding of women in local union leadership. The survey suggests that women's experiences with union leadership are quite similar to that of men, though many survey respondents acknowledge that women sometimes face added pressures, stereotypes, and other obstacles. Although it is clear that male and female officials undergo many of the same problems and concerns, the women are not completely equal to their male counterparts. As expected, female respondents belonged to unions that average lower pay for their members than male respondents' unions, and women respondents personally earned less than the men. The women 
were also largely involved in "women's work," such as teaching and health care. There were few, if any, women employed in higher-paid, historically male work, such as in the railroad industry. A few union men commented that women were not interested in such work because it was too physically demanding. Evidence to support or contradict this assumption will have to be sought in a future study. In order for women to assume leadership roles in such traditionally male fields, one male official said, "First more women should be encouraged to work in a workplace dominated by men." One male letter carrier described how women had made inroads into his previously male occupation: "16 years ago when I started working for the Post Office very few women (2) worked as carriers; Now about 60 percent work as carriers at my post office. District wide this trend holds. As more carriers are women, more women attend meetings and hold positions district and state wide."

With this updated knowledge, union officials can take action to enhance the representation of women in unions. Women officials must ensure that their interests are accounted for and that the values of fairness and respect are extended to all women and all union members. Many of the survey respondents felt that women should play a vital role in the labor movement. Unions, which are increasingly dependent on female members to bolster their membership rosters, may be convinced of the necessity of finding new avenues for female participation and leadership. Women may therefore be afforded advanced opportunities to represent their own interests in the labor organizations that should reflect the interests of all their members.

\section{APPENDIX}

\section{Survey Of Local Union Officials}

\section{Section 1: Local Union Characteristics}

1. To what union/labor organization do you belong? Please provide national affiliation if applicable.

2. What industry or type of workers do you represent?

3. What is the total number of members in your local union?

4. What is the number of female members that belong to your local union? provide a good estimate.)

5. For the past year, what was the average number of members who attended each meeting? (If unknown, please provide a good estimate.)

6. For the past year, what was the average number of female members who attended each meeting? (If unknown, please provide a good estimate.)

7. Within the past five years, how many women (including yourself, if applicable) have served as elected officials in your local union?

8. In the space to the left of each position, please record how many women have held that position within the past five years. (Please include yourself if applicable.)

president vice-president business agent secretary-treasurer secretary treasurer steward other, please specify

9. $\quad$ Does the union provide child care during union meetings?

[] No

[] Yes

If so, please explain the child care arrangements for your union meetings. 
10. Does your local union have one or more women's committees?

[] No

[] Yes

If so, how many female union members belong to the women's committee(s)?

11. What is the average annual pay of the individuals you represent?

[] below $\$ 10,000 \quad$ [] $\$ 40,000-\$ 49,999$

[] $\$ 10,000-\$ 19,999 \quad[] \quad \$ 50,000-\$ 59,999$

$\left[\begin{array}{lll}{[} & \$ 20,000-\$ 29,999 & {[]}\end{array} \$ 60,000-\$ 69,999\right.$

[] $\$ 30,000-\$ 39,999 \quad[] \quad \$ 70,000$ and over

12. With how many different companies/organizations does your local currently have contracts? For teachers, how many schools does your local represent?

\section{Section 2: Opinions And Experiences}

13. Prior to reaching your first elective position in a union, how did you participate in the union? Please put an $\mathrm{X}$ beside all that apply:

[] Was appointed to a position within the union

[] Volunteered for the union

[] Served on a union committee

[] Initiated grievance(s)

[] Attended training program(s) for union members, or training program(s) for management and leadership skills, etc.

[] Ran for election to a union position and did not win

14. Please put an $\mathrm{X}$ by the one statement with which you agree the most:

[] It is much easier for men than women to be elected to office in my union.

[] It is a little easier for men than women to be elected to office in my union.

[] Men and women have the same likelihood of being elected to office in my union.

[] It is a little easier for women than men to be elected to office in my union.

[] It is much easier for women than men to be elected to office in my union.

15. Please put an $\mathrm{X}$ by the one statement with which you agree the most:

[] My local union needs many more female officials.

[] My local union needs a few more female officials.

[] My local union has about the right number of male and female officials.

[] My local union needs a few more male officials.

[] My local union needs many more male officials.

16. Have you ever personally experienced sexual harassment in any unionized workplace? (The EEOC has defined sexual harassment as follows: "Unwelcome sexual advances, requests for sexual favors, and other verbal or physical conduct of a sexual nature constitute sexual harassment when submission to such conduct is made... a term or condition of an individual's employment,... or such conduct has the purpose or effect of unreasonably interfering with an individual's work performance or creating an intimidating, hostile, or offensive working environment," EEOC Guidelines, 29 C.F.R. Section 1604 [1989]: 193-203).

[] No

[] Yes

17. Have you ever personally witnessed sexual harassment of female coworkers in any unionized workplace?

[] No

[] Yes

18. Have you ever personally witnessed sexual harassment of male coworkers in any unionized workplace?

[] No

[] Yes 
19. Have you had to make any personal sacrifices to carry out your union duties?

[] No

[] Yes

If so, what were they?

20. Do you believe female union members face any barriers to elective or appointive office in your union, based on their gender?

[] No

[] Yes

If so, what are they?

21. Have you personally faced any barriers to office?

[] No

[] Yes

If yes, what were they?

And how did you overcome these barriers?

22. Have the officials of your union made any effort to recruit women for leadership positions within the union?

[] No

[] Yes

If so, please describe.

23. Do you think union leadership should take more action to encourage more female participation and leadership in unions?

[] No

[] Yes

If yes, what action(s) should they take?

24. Do you believe that women officials are different than male officials, in leadership style or activities?

[] No

[] Yes

Why or why not? 


\section{Section 3: Descriptive Information}

25. Your gender:

[] Male

[] Female

26. What is your primary occupation, or if retired, what was your primary occupation?

27. How long have you been/were you in this occupation?

28. How long have you been a member of your local union?

29. What is your primary, official position within the union?

30. How long have you held this position?

31. How long is one term of office for this position?

32. When does your term expire?

33. Is this position unpaid or paid?
[] Unpaid
[] Paid
If paid, what is the annual salary for your position in the union?

34. Is your official position with the union your full-time employment (approximately 40 hours per week)?

[] No

[] Yes (If yes, please skip \#35)

35. Is your job a supervisory position (i.e. managing or overseeing other employees)?
[] No
[] Yes
[] Other, please explain

36. Do you currently hold any other positions in your union, such as committee chair, etc.?
[] No
[] Yes
If yes, what other positions do you currently hold in your union?

37. Have you held any other positions that you do not hold anymore, in your current or any former union?

[] No

[] Yes

If yes, what positions have you held that you do not hold anymore, in your current or any former union?

38. Do you hold or have you held any position(s) in a union-affiliated organization such as on central labor council or state AFL-CIO?
[] $\quad$ No
[] Yes
If yes, what position(s)?

39. Do you plan to run for election to a higher office in your union anytime in the future?

[] No

Why not?

[] Yes

[] Not sure

40. What is your age?

41. At what age did you first attain an elective position within your current or any former local union?

42. What is your marital status?

[] Never Married

[] Married

[] Separated 


\begin{tabular}{|c|c|c|c|c|}
\hline & [] & \multicolumn{3}{|l|}{ Divorced } \\
\hline & [] & \multicolumn{3}{|l|}{ Widowed } \\
\hline \multirow[t]{4}{*}{43.} & \multicolumn{4}{|c|}{ Do you have any children? } \\
\hline & [] & \multicolumn{3}{|l|}{ No } \\
\hline & [] & \multicolumn{3}{|c|}{ Yes } \\
\hline & & \multicolumn{3}{|c|}{ If yes, what are the age(s) of your children? } \\
\hline \multirow[t]{7}{*}{44.} & & jel of education hav & om & \\
\hline & [] & \multicolumn{3}{|c|}{ Some high school } \\
\hline & [] & \multicolumn{3}{|l|}{ High school } \\
\hline & [] & \multicolumn{3}{|c|}{ Some college or tech school } \\
\hline & [] & \multicolumn{3}{|c|}{ College degree } \\
\hline & [] & \multicolumn{3}{|l|}{ Some postgraduate } \\
\hline & [] & \multicolumn{3}{|l|}{ Postgraduate degree } \\
\hline \multirow[t]{5}{*}{45.} & \multicolumn{4}{|c|}{ What is your annual pay? } \\
\hline & [] & below $\$ 10,000$ & [] & $\$ 40,000-\$ 49,999$ \\
\hline & [] & $\$ 10,000-\$ 19,999$ & [] & $\$ 50,000-\$ 59,999$ \\
\hline & [] & $\$ 20,000-\$ 29,999$ & [] & $\$ 60,000-\$ 69,999$ \\
\hline & [] & $\$ 30,000-\$ 39,999$ & [] & $\$ 70,000$ and over \\
\hline \multirow[t]{7}{*}{46.} & \multicolumn{4}{|c|}{ Your racial or ethnic identity: } \\
\hline & [] & \multicolumn{3}{|c|}{ African American/African/Black } \\
\hline & [] & \multicolumn{3}{|c|}{ Latin American/Hispanic } \\
\hline & [] & \multicolumn{3}{|c|}{ Caucasian/White } \\
\hline & [] & \multicolumn{3}{|c|}{ Asian-American/Asian/Pacific Islander } \\
\hline & [] & \multicolumn{3}{|c|}{ Native American/Alaskan Native } \\
\hline & [] & \multicolumn{3}{|c|}{ Other } \\
\hline 47. & & itional comments y & wis & dd: \\
\hline
\end{tabular}

Thank you very much for your assistance in our research.

\section{END NOTES}

${ }^{1}$ Cobble, D.S. Ed. Women and Unions: Forging a Partnership; ILR Press, Cornell University: Ithaca, NY, $1993 ; 18$.

${ }^{2}$ Kosterlitz, J. Luring Women to Labor's Ranks. The National Journal 1997, 29(11), 541.

${ }^{3}$ Union Members in 2000. Breau of Labor Statistics: Washington, DC, 2001; January.

${ }^{4}$ Hartmann, H., Spalter-Roth, R., and Collins, N. What Do Unions Do for Women? Challenge 1994, $37(4), 11$.

${ }^{5}$ Forrest, A.What Do Women Want from Union Representation? Hecate 2000, 26(2), 47-62.

${ }^{6}$ Needleman, R. and Tanner, L.D. Women in Unions: Current Issues. In Working Women: Past, Present, Future; Koziara, Karen Shallcroos, Moskow, Michael, Tanner, and Lucretia, Dewey, Eds. The Bureau of National Affairs, Inc: Washington, DC, 1987.

${ }^{7}$ Employment and Earnings. Bureau of Labor Statistics: Washington, DC, 1998; January.

${ }^{8}$ Byrd, B. Women in Carpentry Apprenticeship: A Case Study. Labor Studies Journal 1999, 24(3), 3-23.

${ }^{9}$ Colatosti, C. Misrepresented. The Progressive 1996, 60(8), 36.

${ }^{10}$ Roby, P., and Uttal, L. Putting It All Together: The Dilemmas of Rank-and-File Union Leaders. In Women and Unions: Forging a Partnership, Cobble, Dorothy Sue, Ed.; Ithaca, NY: ILR Press: Ithaca, NY (Cornell University), 1993.

${ }^{11}$ Waldman, A. Labor's New Face. Nation 1997, 265(8), 11-15.

${ }^{12}$ Melcher, D. and Eichstedt, J.L. Women's Participation in Local Union Leadership: The Massachusetts Experience. Industrial \& Labor Relations Review 1992, 45(2), 267.

${ }^{13}$ Elkiss, H. (1994). Training Women for Union Office: Breaking the Glass Ceiling. Labor Studies Journal 1994, 19(2), $25-42$.

${ }^{14}$ Fellner, Kim. Comments. In Women and Unions: Forging a Partnership, Cobble, Dorothy Sue, Ed.; Ithaca, NY: ILR Press: Ithaca, NY (Cornell University), 1993. 